\title{
KELEMBAGAAN KEUANGAN MENDUKUNG INDUSTRI PENANGKAPAN TUNA DI INDONESIA
}

\author{
Charles Bohlen Purba'), John Haluan ${ }^{1)}$, Domu Simbolon²), dan Sugeng H. Wisodo' \\ 1) Staf pada Departemen Keuangan-Jakarta \\ 2) Dosen pada Institut Pertanian Bogor-Bogor \\ Teregristrasi I tanggal: 6 Pebruari 2007; Diterima setelah perbaikan tanggal: 26 Maret 2008; \\ Disetujui terbit tanggal: 25 April 2008
}

\begin{abstract}
ABSTRAK
Perikanan tuna berpeluang dikembangkan di Indonesia. Kekurangan dana dan perhatian institusi perbankan merupakan salah satu kendala. Pada dasarnya terdapat beberapa skema pembiayaan yang dapat digunakan pengusaha untuk pengembangan usaha perikanan tuna. Skema tersebut dibahas pada makalah ini. Salah satu skema tersebut adalah lembaga keuangan non bank yang dikembangkan secara bersama oleh perbankan dan masyarakat. Pemerintah patut melakukan sosialisasi pada perbankan tentang peluang pengembangan usaha di bidang perikanan tuna.
\end{abstract}

KATA KUNCl: perikanan tuna, skema pembiayaan

ABSTRACT: Financial institution supporting Indonesia's Tuna Fishing Industry. By: Charles B. Purba, John Haluan, Domu Simbolon, and Sugeng $\boldsymbol{H}$. Wisodo.

Tuna fishery has an opportunity to be developed in Indonesia. However, financial unavailabity and unawareness of banking institutions are hindrances of development. There are several financial schemes that can be used to develop tuna fishery that are elaborated in this paper. One of those are non banking institution that is co established by banking institution and fishermen. The government should provide information to and aware banking institutions on tuna fishing opportunity and its business prospects.

\section{KEYWORDS: tuna fishing, financial scheme}

\section{LATAR BELAKANG}

Sumber daya ikan yang hidup di wilayah perairan Indonesia memiliki tingkat keragaman hayati yang tinggi. Menurut Kantor Menteri Negara Lingkungan Hidup, sumber daya tersebut paling tidak mencakup 37\% dari spesies ikan di dunia. Di wilayah perairan laut Indonesia terdapat beberapa jenis ikan bernilai ekonomis tinggi antara lain: tuna, cakalang, udang, tongkol, tenggiri, kakap, cumi-cumi, ikan-ikan karang (kerapu, baronang, dan udang barong atau lobster), ikan hias dan kekerangan termasuk rumput laut.
Berdasarkan pada hasil kajian Badan Riset Kelautan dan Perikanan bekerjasama dengan Lembaga IImu Pengetahuan Indonesia, potensi sumber daya ikan laut Indonesia diperkirakan 6.410 juta ton per tahun, yang terdiri atas perairan wilayah laut teritorial sekitar 4.625 juta ton per tahun dan perairan Zona Ekonomi Ekslusif Indonesia sekitar 1.785 juta ton per tahun. Namun demikian, karena manajemen perikanan menganut azas kehatian-hatian (precautionary approach), maka pemerintah menetapkan jumlah tangkapan yang diperbolehkan $80 \%$ dari potensi tersebut 
atau 5,1 juta ton per tahun. Selain potensi tersebut, Indonesia juga memiliki peluang untuk memanfaatkan potensi sumber daya ikan yang ada di laut lepas (open sea).

Tingkat pemanfaatan sumber daya ikan laut pada tahun 2002 telah mencapai sekitar $70 \%$ dari potensi lestarinya atau 4,5 juta ton. Tingkat pemanfaatan tersebut selain terbatas juga belum merata di seluruh wilayah perairan, bahkan beberapa jenis ikan di perairan-perairan tertentu utamanya perairan pantai (<12 mil) sudah intensif dan menunjukkan status lebih-tangkap (overfishing), seperti di Laut Jawa dan Selat Malaka.

Ikan tuna tergolong jenis scombrid yang sangat aktif dan pada umumnya menyebar di perairan yang oseanik sampai dengan ke perairan dekat pantai. Pergerakkan (migrasi) kelompok ikan tuna di wilayah perairan Indonesia mencakup wilayah perairan pantai, teritorial dan Zona Ekonomi Ekslusif Indonesia. Keberadaan tuna di suatu perairan sangat bergantung pada beberapa hal yang terkait dengan spesies tuna, kondisi hidro oseanografi perairan. Wilayah perairan Zona Ekonomi Ekslusif Indonesia merupakan bagian dari jalur migrasi tuna dunia karena wilayah Indonesia terletak pada lintasan perbatasan perairan antara Samudera Hindia dan Pasifik. Migrasi kelompok tuna yang melintasi wilayah perairan pantai dan teritorial terjadi karena perairan tersebut berhubungan langsung dengan pengaruh perairan ke-2 samudera tersebut sehingga beberapa wilayah perairan pantai dan teritorial memiliki sumber daya perikanan tuna yang besar.

Kelompok tuna merupakan jenis kelompok ikan pelagis besar, yang secara komersial dibagi atas kelompok tuna besar dan kecil. Tuna besar terdiri atas jenis ikan tuna mata besar (bigeye-Thunnus obesus), madidihang (yellowfin-Thunnus albacares), tuna albakora (albacore-Thunnus alalunga), tuna sirip biru selatan (southern blue-finThunnus maccoyii), dan tuna abu-abu (longtail tuna-Thunnus tonggol), sedangkan yang termasuk tuna kecil adalah cakalang (skipjack-Katsuwonus pelamis). Sumber daya ikan tuna menyebar tidak merata di seluruh wilayah perairan Indonesia, demikian juga dengan tingkat pemanfaatannya.

Sampai saat ini beberapa permasalahan yang terdapat dalam pengembangan industri penangkapan tuna di Indonesia meliputi:

1. Lembaga-lembaga keuangan resmi, seperti bank, yang ada di Indonesia belum memasukkan sektor industri hasil perikanan tangkap sebagai salah satu sektor yang dapat diberikan kredit atau pinjaman.

2. Belum adanya bentuk baku analisis investasi yang obyektif atas sektor industri hasil perikanan tangkap untuk mendapatkan pinjaman atau kredit.

3. Lembaga-lembaga keuangan yang dapat memberikan pinjaman atau kredit untuk industri hasil perikanan tangkap di Indonesia belum terpetakan dengan baik, terutama distribusi dan kekuatan dananya.

Dalam rangka mencari alternatif pemecahan masalah-masalah tersebut tulisan ini bertujuan untuk:

1. Mengidentifikasi lembaga-lembaga keuangan yang ada di Indonesia, yang telah memasukkan pembiayaan industri hasil perikanan tangkap sebagai salah satu sektor yang dapat diberikan kredit atau pinjaman.

2. Menganalisis investasi yang dapat menghasilkan keuntungan atas pinjaman atau kredit yang diberikan bagi industri hasil perikanan tangkap. 
3. Membentuk suatu opini yang obyektif bahwa lembaga keuangan dengan senang hati akan memberikan pinjaman pada industri hasil perikanan tangkap di Indonesia.

\section{Kendala Industri Perikanan Tuna}

Pada dasarnya kegiatan usaha atau industri perikanan tangkap dapat dibagi dalam 3 kategori skala usaha, yakni skala usaha besar, menengah, dan kecil. Upaya pengembangan terhadap ke-3 skala industri perikanan tangkap tersebut membutuhkan modal (investasi dan modal kerja) yang tidak sedikit. Pengusahaan industri perikanan tangkap skala besar dilakukan oleh pihak Badan Usaha Milik Negara yang mana perolehan modal investasi dan modal kerja pada umumnya diperoleh dari bantuan pemerintah. Sedangkan pengusahaan industri perikanan tangkap skala menengah dilakukan oleh pihak swasta yang mana perolehan modal investasi dan modal kerja pada umumnya diperoleh dari bantuan lembaga keuangan (bank). Pengusahaan terhadap ke-2 jenis skala industri perikanan tangkap ini tidak banyak menghadapi kendala, karena masing-masing pihak (baik peminjam dana maupun lembaga keuangan yang terlibat) sama-sama bertanggungjawab terhadap kelangsungan kegiatan yang dilakukan.

Berbeda dengan pengusahaan industri perikanan tangkap skala besar dan menengah di atas, pengelolaan industri perikanan tangkap skala kecil (tradisional) justru menghadapi banyak permasalahan. Secara umum, dapat diangkat 4 faktor dominan yang mempengaruhi keberhasilan upaya pengembangan industri perikanan tangkap skala kecil (tradisional), yakni (Tri, 1995; 1996):

\section{Pemasaran}

Produk perikanan mudah rusak dan tidak tahan lama (high perishable), sehingga pelaku industri perikanan tangkap skala kecil (tradisional) ini selalu berada pada posisi sulit untuk berkembang akibat harga jual produk yang diterima sangat rendah dan cenderung tidak sebanding dengan resiko maupun biaya yang telah dikeluarkan.

\section{Produksi}

Industri perikanan tangkap di laut sangat berbeda dengan industri lainnya, sulit diprediksi keberhasilannya karena sangat peka terhadap faktor eksternal (musim dan iklim) serta faktor internal (teknologi, sarana, dan prasarana penangkapan ikan dan modal). Kerentanan dalam proses produksi mengakibatkan ada fluktuasi dalam perolehan hasil tangkapan.

\section{Organisasi}

Kelembagaan dalam pengelolaan industri perikanan tangkap skala kecil (tradisional) diakui berada dalam taraf mencari bentuk kelembagaan yang tepat di dalam mengelola sumber dayanya, baik ditinjau dari aspek aturan main maupun organisasi. Konsekuensi dari organisasi dan aturan main yang belum kuat tersebut memberikan dampak pada lemahnya posisi usaha skala kecil ini dalam melakukan negosiasi dengan pihak lain. Berbagai upaya telah dilakukan oleh berbagai pihak dalam rangka menguatkan aspek organisasi ini, sehingga timbul adanya polapola kemitraan antara pelaku usaha skala kecil dengan mitra. Namun, kebanyakan program pengembangan tersebut berjalan relatif tidak lancar. 


\section{Keuangan dan Permodalan}

Salah satu isu masalah pokok yang krusial dan selalu menjadi momok pada industri perikanan tangkap skala kecil (tradisional) adalah permasalahan keuangan dan permodalan. Keterbatasan sumber modal ini bukan disebabkan oleh karena tidak adanya lembaga keuangan dan kurangnya uang beredar, namun disebabkan oleh karena tidak beraninya lembaga keuangan berkecimpung pada kegiatan usaha ini. Kondisi tersebut memang beralasan (bila ditinjau dari sisi ekonomi) karena kegiatan usaha penangkapan ikan skala kecil (tradisional) ini diperparah oleh ketidakpastian dalam memperoleh hasil tangkapan. Sangat wajar apabila lembaga keuangan menghindari rasa ketakutan yang besar terhadap resiko kredit macet (Tjiptono, 1995). Dalam kasus seperti ini lembaga keuangan menetapkan syarat agunan (collateral) yang tinggi dan sulit untuk dapat dipenuhi oleh para pelaku usaha penangkapan ikan skala kecil (tradisional).

\section{Sumber Pendanaan Usaha}

Sumber pendanaan untuk industri perikanan tuna sampai dengan saat ini telah banyak dikenal, yakni:

1. Perbankan: Skim komersial, skim syariah, dan skim kredit program bersubsidi.

2. Non Perbankan: Keuntungan BUMN, modal ventura, dan permodalan nasional madani.

3. APBN: Bantuan luar negeri

4. Sumber lain: Individu, koperasi, perusahaan, yayasan, bursa efek, lembaga dana dan kredit pedesaan, dan swadaya masyarakat

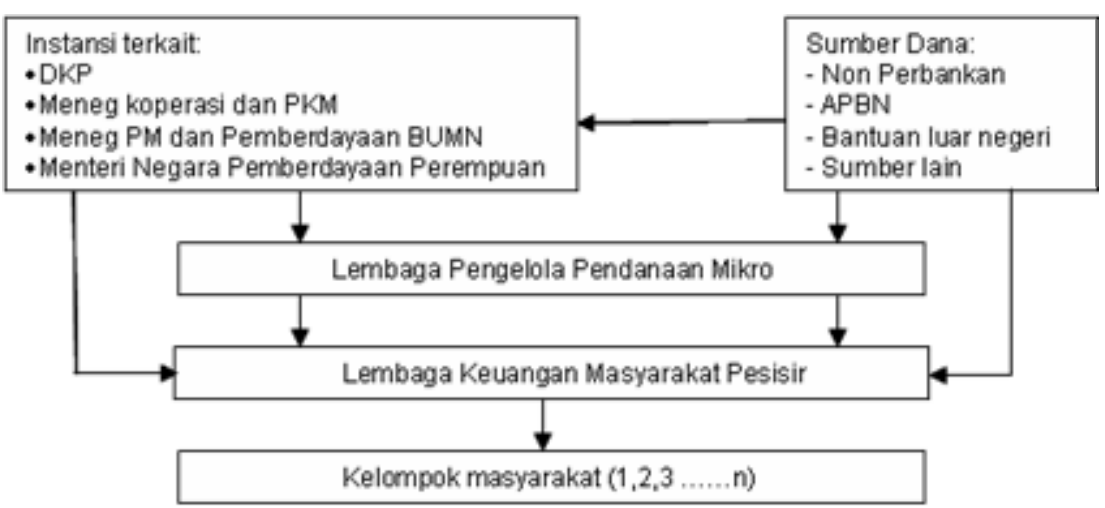

Gambar 1. Sumber dan model pendanaan usaha industri perikanan tangkap.

Figure 1. Source and model of budgeting capture fisheries industri for bussines.

Adapun mekanisme penyaluran pendanaan dan pembinaannya selain sumber perbankan secara garis besar dapat dikatakan sebagai berikut (Gambar 1):

a. Dana disalurkan melalui instansi terkait atau langsung pada lembaga pengelola dana mikro, yaitu sebuah organisasi yang bersifat nirlaba, berbadan hukum dan memenuhi semua persyaratan sesuai peraturan yang berlaku serta berpengalaman di bidang pengelolaan penyaluran pendanaan mikro dan pengembangan masyarakat; atau langsung disalurkan melalui Lembaga Keuangan Masyarakat Pesisir setempat, yaitu unit lapangan dari Lembaga Pengelola Dana Mikro. 
b. Kemudian dana tersebut disalurkan pada kelompok masyarakat yang terdiri atas sekitar 5 anggota, di mana setiap anggota tidak diperbolehkan memiliki hubungan keluarga.

Mekanisme penyaluran sumber pendanaan yang berasal dari perbankan mengikuti prosedur standar komersial di mana calon nasabah dapat memperoleh informasi di kantor perwakilan bank yang bersangkutan. Sampai dengan saat ini, model-model pendanaan untuk industri perikanan tangkap, terutama nelayan tradisional yang telah direalisasikan sebagai berikut:

\section{a. Grameen Bank}

Grameen Bank adalah model pendanaan skala kecil untuk mengembangkan usaha ekonomi produktif masyarakat pesisir (termasuk di dalam industri perikanan tangkap skala kecil) melalui penyediaan modal, pembinaan usaha secara kontinu dan intensif, dan pendampingan berkelanjutan yang mandiri.

\section{b. Model Pembinaan Usaha Kecil oleh BUMN}

Model pembinaan usaha kecil oleh BUMN adalah sebuah model pembinaan dengan memanfaatkan dana dari bagian laba BUMN, di mana pembinaannya dapat berupa pendidikan, kemampuan kewirausahaan, manajemen, serta keterampilan teknis produksi termasuk juga pinjaman modal kerja dan investasi, jaminan kredit, pemasaran dan promosi hasil produksi, serta bantuan penyertaan. Misalnya pemerintah telah mengeluarkan kebijakan berupa (i) kebijakan memberikan sebagian laba (keuntungan) Badan Usaha Milik Negara (1 sampai 5\%) dan (ii) kebijakan alokasi subsidi non bahan bakar minyak. Bahkan telah dikembangkan lembaga keuangan mikro dengan menerapkan sistem kredit komersial pada tingkat bunga yang serendah mungkin, di mana pemerintah dapat berperan sebagai penjamin dan pembina teknis, sementara pihak perbankan berperan dalam penyediaan modal dan pembinaan manajemen keuangan dan organisasi.

\section{c. Model Kemitraan}

Kemitraan adalah kerja sama antara usaha kecil dengan usaha menengah atau usaha besar, di mana terjadi proses pembinaan dan pengembangan terhadap usaha kecil oleh usaha menengah atau usaha besar dengan memperhatikan prinsip saling memerlukan, saling memperkuat dan saling menguntungkan (Kotler, 1997; Kotler \& Armstrong, 1997). Misal, sejak tahun 2000 pemerintah juga menerapkan sistem dana bergulir dalam program pemberdayaan ekonomi pesisir yang bukan bersifat charity (hadiah), tetapi lebih diarahkan untuk empowerment (pemberdayaan), sehingga diharapkan dapat terus berkembang dan menyentuh sebagian besar masyarakat pesisir atau nelayan. Dana bergulir dari pemerintah yang dikelola Lembaga Ekonomi Pengembangan Pesisir disampaikan langsung pada masyarakat pesisir atau nelayan sebagai stakeholders utama dengan fokus pada peningkatan lapangan kerja dan kesempatan berusaha, berbasis pada sumber daya lokal, berorientasi pada masa depan dan berkelanjutan, serta bertumpu pada pengembangan sumber daya manusia dan penguatan kelembagaan lokal yang bersifat partisipatif. Untuk mencapai tujuan strategis tersebut, telah dibentuk kelembagaan usaha berupa Lembaga Ekonomi Pengembangan Pesisir Mikro Mitra Mina sebagai embrio badan usaha untuk membantu pengembangan usaha produktif masyarakat pesisir. Sebagian besar Lembaga Ekonomi Pengembangan Pesisir 
berfungsi sebagai Lembaga Keuangan Mikro yang kegiatan terbatas pada perguliran dana produktif yang dialokasikan pemerintah. Dalam hal ini pihak Departemen Kelautan dan Perikanan menggandeng P.T. Permodalan Nasional Madani (Persero) dan Pemerintah Daerah, untuk memperkuat dan merevitalisasi Lembaga Ekonomi Pengembangan Pesisir menjadi bank pesisir yang mengakar dan berlandaskan keswadayaan masyarakat yang berkelanjutan.

\section{Lembaga Keuangan Non Bank}

Pembiayaan perikanan tuna dapat juga dilakukan oleh lembaga khusus keuangan yang bukan bank, seperti koperasi simpan pinjam. Jika hanya mengandalkan perbankan, akan sulit bagi perikanan rakyat untuk mendapatkan akses pembiayaan karena semua persyaratan perbankan harus dipenuhi.

Seperti diketahui bahwa perbankan belum tertarik untuk bergerak di pembiayaan sektor perikanan. Hal ini, semata-mata karena kurang daya tarik sektor perikanan, antara lain karena tidak cepat menghasilkan, risiko tinggi oleh faktor alam, produk cepat rusak atau busuk, dan memerlukan peralatan yang banyak dan mahal. Namun, untuk mengatasi masalah tersebut prinsip sederhana, ada gula ada semut. Pemerintah membuat sektor perikanan menarik bagi lembaga keuangan, pelaku, maupun investor. Malaysia dan Thailand berhasil melakukan itu, dapat mengendalikan risiko-risiko yang ada dengan teknologi. Pemerintah dapat membantu menciptakan daya tarik perikanan dengan mengembangkan infrastruktur perikanan, memberikan insentif bagi investor yang masuk ke sektor perikanan, dan memberikan kepastian usaha. Oleh karena itu, pemerintah merevitalisasi Departemen Kelautan dan
Perikanan karena lembaga tersebut yang bertanggungjawab dalam urusan sumber daya manusia, teknologi perikanan, data stok sumber daya perikanan, dan perizinan. Sehingga pemerintah menunjukkan keberpihakan pada sektor perikanan, bahwa sektor perikanan akan mempengaruhi pada kebijakan makro ekonomi negara ini.

Keterbatasan akses permodalan ditandai dengan realisasi modal melalui investasi pemerintah dan swasta selama periode pembangunan jangka panjang tahap pertama yang hanya $0,02 \%$ dari keseluruhan modal pembangunan. Konsekuensi, terutama nelayan, kebutuhan permodalan dipenuhi oleh para tengkulak, toke, atau ponggawa, yang kenyataan tidak banyak menolong untuk meningkatkan kesejahteraan, malah cenderung menjerat dalam lilitan utang yang tidak pernah dapat dilunasi.

Melihat kenyataan ini, Departemen Kelautan dan Perikanan menginisiasi program Pemberdayaan Ekonomi Masyarakat Pesisir. Program ini pun berhasil mengangkat pendapatan dan kesejahteraan masyarakat pesisir. Sukses yang diraih itu belum memuaskan, karena ada obsesi untuk menjadikan profesional dan mandiri para pengelola Koperasi Lembaga Ekonomi Pengembangan Pesisir Mikro Mitra Mina. Untuk itu, Departemen Kelautan dan Perikanan bekerjasama dengan P.T. Bank Bukopin mendirikan sebuah Lembaga Keuangan Mikro Swamitra Mina. Hadirnya lembaga ini di masyarakat pesisir akan menjadi lokomotif permodalan bagi masyarakat pesisir. Lembaga ini telah hadir di 139 kabupaten atau kota. Launching Lembaga Keuangan Mikro Swamitra Mina telah dilaksanakan dan diresmikan oleh Menteri Kelautan dan Perikanan Freddy Numberi pada tanggal 12 Desember 2004 di Cilincing, Jakarta Utara. 
Cikal bakal pelaksanaan program Swamitra Mina bermula dari program Pemberdayaan Ekonomi Masyarakat Pesisir. Pada tahun 2004 program Pemberdayaan Ekonomi Masyarakat Pesisir mendapat kucuran dana Rp.140 milyar untuk mengakomodir 160 kabupaten atau kota. Adapun pagu untuk dana ekonomi produktif yang digunakan sebagai penguatan modal Rp.98.347.592,000 yang dikelola melalui Lembaga Keuangan Mikro Swamitra Mina, BPR-Pesisir, dan USP. Adapun jumlah Lembaga Keuangan Mikro Swamitra Mina yang ada saat ini 139 buah yang kesemua adalah Koperasi Lembaga Ekonomi Pengembangan Pesisir Mikro Mitra Mina atau Koperasi Perikanan yang telah berbadan hukum. Dengan status berbadan hukum, maka telah memenuhi persyaratan perundang-undangan yang mensyaratkan bahwa untuk menyerap dana masyarakat dan memberikan pinjaman pada masyarakat hanya lembaga perbankan dan koperasi yang berbadan hukum.

Tentu bukan itu persyaratan yang dimiliki Lembaga Keuangan Mikro Swamitra Mina. Selain berbadan hukum, juga harus mempunyai sumber daya manusia yang profesional untuk mengelola, sebab pelaksanaan transaksi di Lembaga Keuangan Mikro ini dilakukan pula secara profesional yaitu penggunaan perangkat teknologi informasi. Dengan demikian, semua transaksi yang terjadi di Lembaga Keuangan Mikro Swamitra Mina sudah dapat dimonitoring secara riel time dan on time.

Dipilihnya Bank Bukopin sebagai Bank Pelaksana didasarkan bahwa hanya Bank Bukopin yang memiliki program Swamitra dan telah banyak sukses di daerah pedesaan seluruh Indonesia. Yang lebih penting bahwa Bank Bukopin punya komitmen untuk berperan sebagai executor dan menyalurkan $100 \%$ dana ekonomi produktif yang dimiliki koperasi Lembaga Ekonomi Pengembangan Pesisir Mikro Mitra Mina. Selain itu, bank ini juga berkomitmen untuk mengadakan pelatihan dan pendampingan bagi pengelola Lembaga Keuangan Mikro Swamitra Mina.

Dengan kerja keras yang dilakukan Departemen Kelautan dan Perikanan, kini telah berdiri 139 Lembaga Keuangan Mikro Swamitra Mina di wilayah pesisir. Dari 139 ini sampai pertengahan bulan Pebruari 2005 tercatat 60 Lembaga Keuangan Mikro Swamitra Mina telah melakukan transaksi pinjaman pada masyarakat, dan diharapkan pada akhir bulan Maret semua Lembaga Keuangan Mikro ini telah melakukan transaksi pada masyarakat pesisir. Adapun bunga pinjaman yang diterapkan di lembaga ini bervariasi antara 12 sampai dengan $24 \%$ secara efektip per tahun. Bunga pinjaman ini dirasakan masyarakat pesisir cukup kompetitif. Begitu pula variasi bunga pinjaman ini sangat dipengaruhi oleh situasi, kondisi, dan kesepakatan masyarakat pesisir setempat.

Memang disadari bahwa dalam mengelola Swamitra Mina karena lokasi berada jauh di wilayah pesisir, maka ada 2 tipe pengelolaan yaitu on line dan off line. Apabila di lokasi tersedia jaringan telepon yang secara kualitas dapat dilalui dengan data, maka Lembaga Keuangan Mikro Swamitra Mina seperti ini bisa on line. Begitu pula apabila daerah tersebut tidak mampu mendapatkan jaringan yang layak untuk data, maka akan dikelola secara off line. Walaupun status off line tetap akan disediakan sarana komunikasi. Artinya pencatatan secara komputerisasi tetap dilakukan hanya data tersebut pada waktu tertentu di upload atau dikirim rata-rata 1 sampai dengan 2 minggu sekali, kemudian digabungkan dengan data yang on line dan disatukan kemudian dikirim ke Jakarta. 
Swamitra Mina merupakan unit simpanpinjam milik seluruh masyarakat pesisir yang direpresentasikan oleh Koperasi Lembaga Ekonomi Pengembangan Pesisir Mikro Mitra Mina atau Koperasi Perikanan lain. Swamitra Mina dikelola secara profesional oleh tenaga-tenaga muda pesisir yang sebelumnya telah memperoleh pelatihan dari Bank Bukopin. Dengan pendampingan Bank Bukopin Cabang, Swamitra Mina diharapkan akan menjadi lembaga keuangan mikro terkemuka di daerah pesisir, yang mudah diakses oleh para nelayan dan masyarakat pesisir lain.

Sebagai konsekuensi dari kepemilikan Swamitra Mina, maka nelayan dan masyarakat pesisir akan mendapatkan sisa hasil usaha (deviden) setiap tahun dari keuntungan Swamitra Mina. Selain itu, melalui Swamitra Mina dana masyarakat dapat dimobilisasi melalui tabungan dengan tingkat suku bunga yang kompetitif serta dana dari sumber lain, untuk akhirnya disalurkan kembali ke masyarakat pesisir dari lembaga keuangan lain. Swamitra Mina merupakan proses pembelajaran bagi nelayan dan masyarakat pesisir untuk mengakses dana dari pihak perbankan, begitu pula sebaliknya proses pembelajaran bagi perbankan dalam mengakses masyarakat pesisir.

Agar masyarakat pesisir dapat mengakses dengan mudah Lembaga Keuangan Mikro Swamitra Mina serta mengelola secara efesien modal yang telah diperoleh, maka disediakan tenaga pendamping desa masing-masing 2 orang tiap kabupaten atau kota. Tenaga pendamping desa tersebut terdiri atas sarjana-sarjana baru yang sebelumnya dilatih secara nasional. Selain itu, juga disediakan konsultan manajemen (perguruan tinggi, LSM, atau lembaga konsultan profesional) untuk membantu mengembangkan dan meningkatkan kinerja kelembagaan dan pemasaran.

Hadirnya Lembaga Keuangan Mikro Swamitra Mina di wilayah pesisir, maka secara bertahap peran tengkulak dan rentenir akan berkurang sehingga Lembaga Keuangan Mikro dapat memobilisasi dana masyarakat dengan ada suku bunga tabungan yang menarik. Dengan lancar pengelolaan Lembaga Keuangan Mikro Swamitra Mina, maka perlahan tapi pasti bantuan modal yang disalurkan di masyarakat pesisir bukan lagi berasal dari anggaran pendapatan belanja negara, tapi dari Lembaga Keuangan Mikro Swamitra Mina itu sendiri (Pearce \& Robinson, 1997). Sehingga Lembaga Keuangan Mikro Swamitra Mina semakin dilirik oleh lembaga keuangan lain untuk bermitra mengakses permodalan. Dengan demikian, Lembaga Keuangan Mikro Swamitra Mina sebagai lokomotif dapat menggandeng lembaga keuangan lain dalam kiprah membangun usaha sektor perikanan dan kelautan. (Sumber: Direktorat Program Pemberdayaan Ekonomi Pesisir-Direktorat Jenderal P3K)

\section{REKOMEDASI KEBIJAKAN}

Kelembagaan keuangan pengusahaan industri penangkapan di Indonesia pada umumnya terdiri atas lembaga bank dan non bank. Pengusahaan industri tuna skala kecil sangat mengalami kesulitan dalam memperoleh dana dari lembaga perbankan. Oleh karena itu, kebijakan yang ditempuh dalam mengatasi kesulitan permodalan perikanan tuna skala kecil adalah:

1. Meningkatkan jangkauan dan jumlah dana dalam program dana bergulir ke masyarakat nelayan skala kecil seperti program pemberdayaan ekonomi pesisir yang sudah dilaksanakan Departemen Kelautan dan Perikanan. 
2. Membentuk lembaga penjamin pinjaman untuk pengusahaan perikanan tuna skala kecil sehingga agunan tidak diperlukan lagi dalam peminjaman modal dari bank.

3. Melakukan sosialisasi pada perbankan nasional dan memberikan pemahaman bahwa perikanan tuna secara khusus, dan perikanan tangkap pada umumnya, memiliki peluang usaha yang baik dan karena itu layak untuk didanai melalui dana perbankan.

\section{DAFTAR PUSTAKA}

Tri, C. B. 1995. Manajemen Strategi Pemasaran. Sekolah Tinggi IImu Ekonomi IPWI Program Magister Manajemen. Badan Penerbit IPWI. Jakarta. 1995.

Tri, C. B. 1996. Manajemen Strategi. Sekolah Tinggi Ilmu Ekonomi IPWI. Program Magister Manajemen. Badan Penerbit IPWI. Jakarta. 1996.
Tjiptono, F. 1995. Strategi Pemasaran. Penerbit Andi Offset. Yogyakarta.

Pearce \& Robinson. 1997. Manajemen Strategik. Formulasi, Implementasi dan Pengendalian. Jilid 1. Alih Bahasa Terbitan Pertama Bina Aksara. Jakarta.

Kotler, P. 1997. Manajemen Pemasaran. Marketing Management 9e. Analisis Perencanaan, Implementasi, dan Kontrol. Simon \& Schuster (Asia) Pte. Ltd.

Kotler, P. \& G. Armstrong. 1997. DasarDasar Pemasaran. Principle of Marketing 7. Jilid I. Simon \& Schuster (Asia) Pte. LTd. 